\title{
Response of Soil Chemical Properties to Irrigation with Winery Wastewater on a Well-drained Sandy Soil
}

\author{
A. R. Mulidzi ${ }^{*}$, C. E. Clarke ${ }^{2}$, P. A. Myburgh ${ }^{1}$ \\ (1) Soil and Water Science Division, ARC Infruitec-Nietvoorbij, Private Bag X5026, Stellenbosch 7599, South Africa. \\ (2) Department of Soil Science, Stellenbosch University, Private Bag X1, Matieland 7602, South Africa.
}

Submitted for publication: March 2019

Accepted for publication: June 2019

Keywords: Chemical oxygen demand, Electrical conductivity, Potassium, Sodium adsorption ratio, Soil properties, Wastewater

\begin{abstract}
Most wineries in South Africa dispose of their wastewater through land application. This is carried out by irrigating small areas of cultivated pasture with the wastewater or ponding, with the former being the more general practice. Land application of winery wastewater results in the accumulation of potassium $\left(\mathrm{K}^{+}\right)$and sodium $\left(\mathrm{Na}^{+}\right)$in the soil and leaching of calcium $\left(\mathrm{Ca}^{2+}\right)$ and magnesium $\left(\mathrm{Mg}^{2+}\right)$.This could lead to long term instability of soil structure. The objective of this study was to investigate the effect of irrigation with winery wastewater on chemical soil properties and potential environmental impacts. Therefore, an existing grazing paddock at a winery near Rawsonville was selected where wastewater had been applied for many years. Due to the high volumes of wastewater irrigation plus rainfall, the inevitable over-irrigation leached large amounts of cations, particular $\mathrm{K}^{+}$and $\mathrm{Na}^{+}$, beyond $90 \mathrm{~cm}$ soil depth at the selected study site. These leached elements are likely to end up in natural water resources in the long run. Irrigation with winery wastewater did not have a pronounced effect on soil $\mathrm{pH}_{(\mathrm{KCl})}$. This was probably due to the decomposition of organic matter, and the fact that the applied salts were leached beyond $90 \mathrm{~cm}$ depth. The study confirmed that disposal of winery wastewater through land application can only be recommended where wastewater application will not exceed the water requirement of the crop as well as the water holding capacity of the soil which is being irrigated.
\end{abstract}

\section{INTRODUCTION}

The South African wine industry makes a significant contribution to the economy as well as providing employment opportunities in rural areas (Howell \& Myburgh, 2018). In 2017, the Western Cape experienced the worst drought in decade and this will have a lasting effect on agricultural production for years to come (Mulidzi et al., 2018). The use and availability of wastewater for irrigation have increased globally and the disposal thereof is governed by stringent legislation (Arienzo et al., 2009). Land application of winery wastewater results in the accumulation of potassium $\left(\mathrm{K}^{+}\right)$ and sodium $\left(\mathrm{Na}^{+}\right)$in the soil and leaching of $\mathrm{Ca}^{2+}$ and $\mathrm{Mg}^{2+}$ (Mulidzi et al., 2018). In South Africa, most wineries still dispose of their wastewater through land application and this is carried out by irrigating small areas of cultivated pasture with the wastewater (Mulidzi et al., 2018). Using winery wastewater within the vineyard represents a sustainable approach to minimize off-site environmental impact (Hirzel et al., 2017). The use of winery wastewater for wine grape production is increasing, and it is therefore important to understand the environmental implication of such a practice
(Laurenson et al., 2012).

Although the effects of high $\mathrm{K}^{+}$concentrations in winery wastewater used for irrigation have not yet been researched extensively, it has been suggested that irrigation with $\mathrm{K}^{+}$rich wastewaters could be advantageous to overall soil fertility (Mosse et al., 2011). However, long term application could result in the alteration of physicochemical soil properties. Application of winery wastewater over a long time on pastures resulted in the build-up of available $\mathrm{K}^{+}$levels that had the potential to leach into the groundwater and other water sources (Christen et al., 2010). Application of wastewater with high amounts of $\mathrm{K}^{+}$and $\mathrm{Mg}^{2+}$ resulted in loss of soil structural stability, and reduced hydraulic conductivity (Arienzo et al., 2012). Furthermore, disposal of winery wastewater through land application can increase levels of soil soluble $\mathrm{K}^{+}$and the exchangeable potassium percentage (EPP), since most $\mathrm{K}^{+}$in wastewater is immediately available (Arienzo et al., 2009).

Soils with low clay content retain less $\mathrm{K}^{+}$in the exchangeable form, while soils with higher clay content

\footnotetext{
*Corresponding author: E-mail address: mulidzir@arc.agric.za

Acknowledgements: The Water Research Commission for initiating and funding the project. Winetech, THRIP (TP1208066038) and Agricultural Research Council for co-funding. Staff of Soil and Water Science at ARC Infruitec-Nietvoorbij for technical support, and in particular Mr Francois Baron for his dedicated effort. Any opinions, findings and conclusions or recommendations expressed in any publication generated through THRIP-supported research, are those of the authors and therefore the NRF/THRIP will not accept any liability in that regard
} 
retain $\mathrm{K}^{+}$to a greater extent (Smiles \& Smith, 2004). Another study showed that application of winery wastewater with $\mathrm{K}^{+}$and $\mathrm{Na}^{+}$concentration of approximately $400 \mathrm{mg} / \mathrm{L}$ on pastures and woodlots resulted in accumulation of available $\mathrm{K}^{+}$levels of $1400 \mathrm{mg} / \mathrm{kg}$ over the long term (Kumar et al., 2006). The actual amounts and the ratios between the four dominant basic cations, namely $\mathrm{Ca}^{2+}, \mathrm{Mg}^{2+}, \mathrm{K}^{+}$and $\mathrm{Na}^{+}$, adsorbed on the soil exchange complex, are important with regard to soil chemical and physical conditions, as well as plant nutrition. Adequate $\mathrm{K}^{+}$is, for example, important for grapevine performance and $\mathrm{K}^{+}$deficiencies will cause low yields (Raath, 2012). On the other hand, excessive $\mathrm{K}^{+}$levels can cause poor wine quality in terms of low acidity and poor colouring of red wines (Kodur, 2011). Although there is limited information on the effects of $\mathrm{K}^{+}$on structure stability, it seems that high levels of exchangeable $\mathrm{K}^{+}$, similar to $\mathrm{Na}^{+}$, can increase dispersion resulting in reduced soil hydraulic conductivity and water infiltration rate (Quirck \& Schofield, 1955). The exchangeable cation composition in the soil is extremely important due to the different impacts of different cations with regard to dispersion and flocculation of soil colloids. Dispersion leads to degradation of soil structure, which causes problems such as soil crusting (surface sealing) and slaking that can lead to low water infiltration rates, low hydraulic conductivity, poor aeration, poor root development and functioning (Laker, 2004).

Application of winery wastewater that contain high concentrations of dissolved organic carbon and bicarbonate cleaning products has the potential to increase soil $\mathrm{pH}$ when applied to land (Laurenson \& Houlbrooke, 2012).

Soil $\mathrm{pH}$ increase is due to anion hydrolysis and decarboxylation reactions when cations such as $\mathrm{K}^{+}, \mathrm{Na}^{+}, \mathrm{Ca}^{2+}$ and $\mathrm{Mg}^{2+}$ are applied with plant materials (Yan et al., 1996; Li et al., 2008). Disposal of winery wastewater containing high levels of $\mathrm{P}$ can increase the concentration of dissolved $\mathrm{P}$ in runoff. This risk is greatest when rainfall occurs immediately after application of the wastewater (Mulidzi et al., 2009). Based on the forgoing, the objective of the study was to investigate the effect of winery wastewater irrigation on the soil chemical properties and potential environmental impacts at an existing grazing paddock at a winery near Rawsonville where wastewater had been applied for many years.

\section{MATERIALS AND METHODS}

\section{Experiment site}

The experiment was carried out at a winery near Rawsonville $\left(-33.4137 .7^{\circ} 19.1920 .3^{\circ}\right)$ in an existing cultivated pasture grazing paddock where winery wastewater had been applied for over 15 years. A detailed description of the site was previously reported by Mulidzi (2016).

\section{Soil characteristics}

The soils around Rawsonville were formed from the alluvium of the Breede River. The soil at the site selected for the study showed no clear stratification and contained a mottled subsoil, thus qualifying it for inclusion in the Longlands soil form (Soil Classification Working Group, 1991) or a Gleyic, Albic, Arenosol (IUSS Working Group WRB, 2014). The apedal soil consisted of fine sand. The B horizon showed few fine mottles with distinct contrast and brown colour.

\section{Experiment layout}

Three $2 \mathrm{~m} \times 3 \mathrm{~m}$ replication plots were demarcated on the $1^{\text {st }}$ of July 2010 . Rain gauges were installed in each plot at a height of $0.5 \mathrm{~m}$ to measure the amount of wastewater applied. A two litre plastic bottle was attached to each rain gauge at the irrigation site in order to collect the overflow wastewater when the rain gauge was full. Three rain gauges were also installed outside each paddock for measuring rainfall.

\section{Application of winery wastewater to the soils}

The overhead sprinkler was connected to the main wastewater line through which the winery disposes its wastewater by irrigating kikuyu grass. The volume of wastewater applied and rainfall were recorded weekly by means of rain meters. The field measurements started on 1 March 2011, sampling of winery wastewater commenced in April 2011 and the study ended at the end of November 2013.

\section{Wastewater sampling and analysis}

Winery wastewater sampling and analysis was described by Mulidzi et al. (2018).

\section{Soil sampling and analysis}

Soil samples were collected at the study site before wastewater monitoring began in March 2011. Thereafter, samples were collected annually in May before winter rainfall commences, and in November, after the winter rainfall period. Samples were collected in 2011, 2012 and 2013. Soil was sampled at 0 to $10 \mathrm{~cm}, 10$ to $20 \mathrm{~cm}, 20$ to $30 \mathrm{~cm}, 30$ to $60 \mathrm{~cm}$ and 60 to $90 \mathrm{~cm}$ depth increments. All soil analyses were carried out by a commercial laboratory (Bemlab, Strand). Total organic carbon content was determined using the method described by Walkley and Black (1934).

The $\mathrm{pH}_{(\mathrm{KCl})}$ was determined in a $1 \mathrm{M}$ potassium chloride $(\mathrm{KCl})$ suspension. The $\mathrm{Ca}^{2+}, \mathrm{Mg}^{2+}, \mathrm{K}^{+}$and $\mathrm{Na}^{+}$were extracted with $1 \mathrm{M}$ ammonium acetate at $\mathrm{pH}$ 7. The cation concentrations in the extracts were determined by means of atomic emission using an optical emission spectrometer (Varian ICP-OES). For this article, the cations will be referred to as extractable calcium $\left(\mathrm{Ca}^{2+}{ }_{\text {extr }}\right)$, magnesium $\left(\mathrm{Mg}^{2+}{ }_{\text {extr }}\right)$, potassium $\left(\mathrm{K}^{+}{ }_{\text {extr }}\right)$ and sodium $\left(\mathrm{Na}^{+}{ }_{\text {extr }}\right)$. The extractable potassium percentage $\left(\mathrm{EPP}^{\prime}\right)$ was calculated as follows:

$\mathrm{EPP}^{\prime}=\left(\mathrm{K}_{\text {extr }}^{+} \div \mathrm{S}\right) \times 100$

where $\mathrm{K}_{\text {extr }}^{+}$is the extractable $\mathrm{K}^{+}\left(\mathrm{cmol}_{(+)} / \mathrm{kg}\right)$ and $\mathrm{S}$ is the sum of the basic cations $\left(\mathrm{cmol}_{(+)} / \mathrm{kg}\right)$.

In order to get an indication of the sodicity status of the soil, the extractable sodium percentage $\left(\mathrm{ESP}^{\prime}\right)$ was calculated as follows:

$\mathrm{ESP}^{\prime}=\left(\mathrm{Na}_{\text {extr }}^{+} \div \mathrm{S}\right) \times 100$

where $\mathrm{Na}^{+}$extr is the extractable $\mathrm{Na}^{+}\left(\mathrm{cmol}_{(+)} / \mathrm{kg}\right)$ and $\mathrm{S}$ is the sum of the basic cations $\left(\mathrm{cmol}_{(+)} / \mathrm{kg}\right)$.

Phosphorus was determined according to the Bray No. 2 method, i.e. extraction with $0.03 \mathrm{M} \mathrm{NH}_{4} \mathrm{~F}$ (ammonium fluoride) in $0.01 \mathrm{M} \mathrm{HCl}$ (hydrochloric acid). The $\mathrm{P}$ concentration in the extract was determined by means of atomic emission as mentioned above. The soil cation exchange capacity (CEC) was determined using $0.2 \mathrm{M}$ ammonium acetate $(\mathrm{pH}=7$ as 
extractant of exchangeable cations) method as described by The Non-affiliated Soil Analyses Work Committee (1990).

\section{Statistical procedures}

The experimental design was a randomised complete block with seven sampling times randomly replicated within each of three blocks. At each sampling time, determinations were made at five soil depth intervals. Univariate analysis of variance was performed, for each depth interval separately, on all variables assessed using GLM (General Linear Models) Procedure of SAS statistical software (Version 9.2; SAS Institute Inc., Cary, NC, USA). Values for different depth intervals were also combined in a split-plot analysis of variance with depth as sub-plot factor (Snedecor, 1980). Shapiro-Wilk test was performed to test for normality (Shapiro \& Wilk, 1965). Student's t-least significant difference was calculated at the 5\% level to compare treatment means (Ott, 1998). A probability level of $5 \%$ was considered significant for all significance tests.

\section{RESULTS AND DISCUSSION}

\section{Chemical composition of winery wastewater}

Basic cations: It was evident that the wastewater contained high amounts of $\mathrm{K}^{+}$and $\mathrm{Na}^{+}$which could have a negative impact on the soil (Fig. 1A). On average, $\mathrm{K}^{+}$levels in the wastewater were substantially higher than the levels of $\mathrm{Na}^{+}$. This indicated that the winery probably used more $\mathrm{K}^{+}$containing detergents than $\mathrm{Na}^{+}$based ones. The annual fluctuation in $\mathrm{K}^{+}$and $\mathrm{Na}^{+}$could not be related to specific seasonal activities in the winery, e.g. grape crushing or bottling. However, almost throughout the entire study period the $\mathrm{Na}^{+}$was higher than $70 \mathrm{mg} / \mathrm{L}$, i.e. the upper threshold for unrestricted use for sprinkler irrigation (Ayers \& Westcot, 1994). The levels of $\mathrm{Ca}^{2+}$ and $\mathrm{Mg}^{2+}$ in the wastewater were substantially lower than the monovalent ions (Fig. 1B). This was to be expected, since chemicals containing $\mathrm{Ca}^{2+}$ and $\mathrm{Mg}^{2+}$ do not play a prominent role in winery processes. At these low levels the bivalent ions would not have any negative effects on soils or crops. However, the $\mathrm{Ca}^{2+}$ and $\mathrm{Mg}^{2+}$ could have some positive effect on the water quality by reducing the SAR.

SAR: In 2011, the winery wastewater SAR was frequently higher than 5, the legal limit for irrigation with wastewater as stipulated in the Department of Water Affairs (2013) General Authorisation (Fig. 1C). During the remainder of the study period, the SAR was mostly equal to, or below the legal limit. It should be noted that the wastewater SAR did not follow a distinct annual pattern that could be related to specific activities in the winery.

$\boldsymbol{E C}$ : The winery wastewater EC was below the permissible limit of $2 \mathrm{dS} / \mathrm{m}$, as stipulated in the Department of Water Affairs (2013) General Authorisation for irrigation with wastewater, except for prominent spikes in January 2012 and June 2013 (Fig. 1D). Similar to the SAR, the EC did not follow a distinct annual pattern that could be related to specific winery activities.

Anions: Similar to the cations, the variation in levels of $\mathrm{HCO}_{3}^{-}$, as well as $\mathrm{SO}_{4}^{2-}$ and $\mathrm{Cl}^{-}$could not be related to a specific activity in the winery (Fig. 2A \& B). During February and March 2013, the level of $\mathrm{Cl}^{-}$was above the
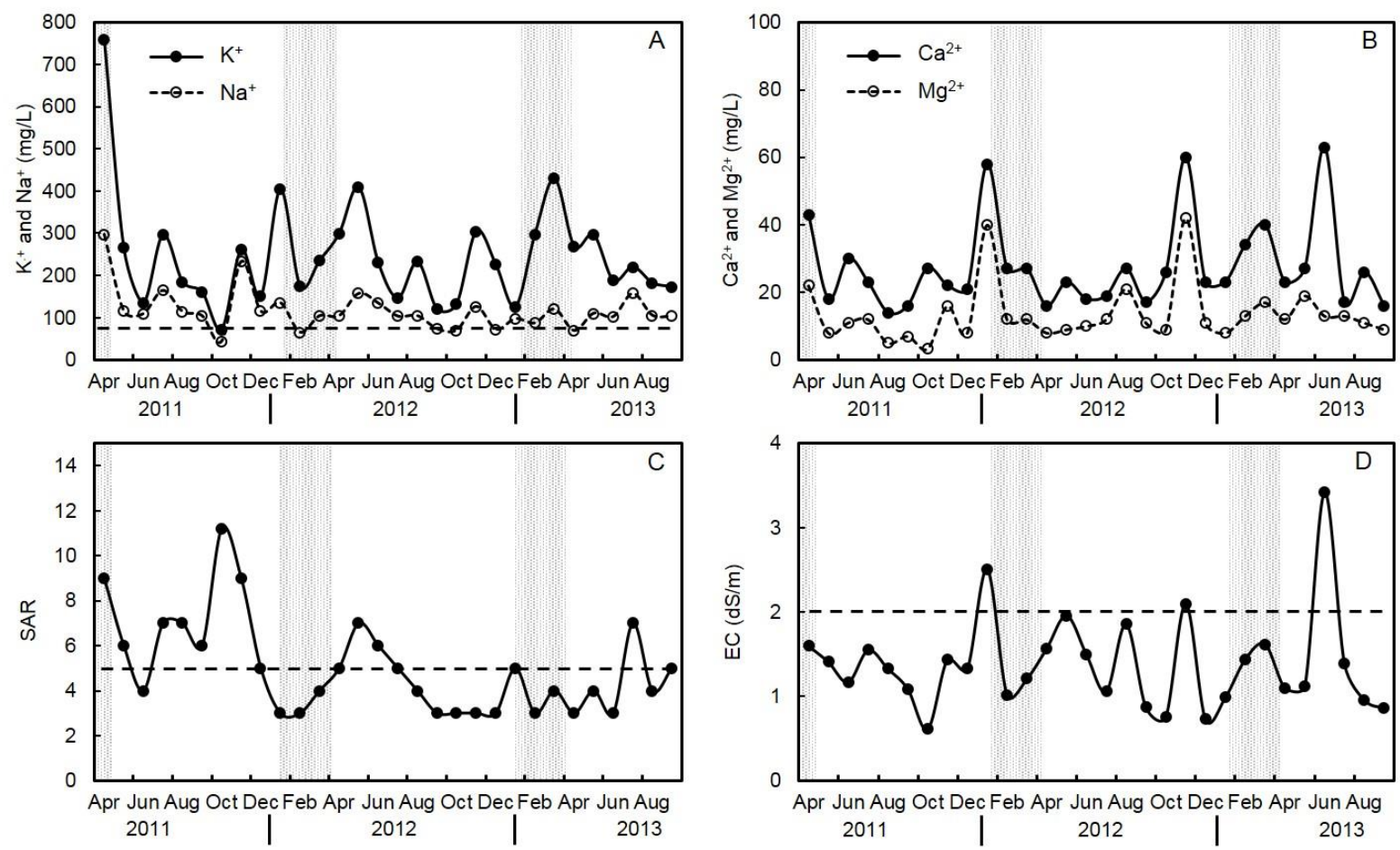

FIGURE 1

Temporal variation in (A) $\mathrm{K}^{+}$and $\mathrm{Na}^{+}$, (B) $\mathrm{Ca}^{2+}$ and $\mathrm{Mg}^{2+}$, (C) sodium adsorption ratio (SAR) and (D) electrical conductivity (EC) in wastewater from a winery near Rawsonville. Shaded columns indicate the harvest periods. Dashed lines indicate the $\mathrm{Na}^{+}, \mathrm{SAR}$ and EC thresholds for irrigation water. 
recommended threshold of $150 \mathrm{mg} / \mathrm{L}$ for vineyard irrigation (Howell \& Myburgh, 2013, and references therein) (Fig. 2B).

Phosphorus: Since the levels of $\mathrm{P}$ were generally low throughout the study period (Fig. 2B), land application of the wastewater would not make a significant contribution to the $P$ requirements of crops.

$\boldsymbol{p H}$ : With the exception of November and December 2011, the winery wastewater $\mathrm{pH}$ was generally equal to or less than 6 , the lower limit for wastewater irrigation as stipulated in the Department of Water Affairs (2013) General Authorisation (Fig. 2C). Annually, the pH tended to be higher in winter than during the harvest period. Since the $\mathrm{pH}$ was below the legal requirement for disposal through land application during these periods, it was not suitable for irrigation of crops.

COD: Throughout the study period, the winery wastewater COD was considerably higher than $400 \mathrm{mg} / \mathrm{L}$, the upper limit for wastewater irrigation where $500 \mathrm{~m}^{3}$ of wastewater is applied per day as stipulated in the Department of Water Affairs (2013) General Authorisation (Fig. 2D). Therefore, the wastewater did not comply with the legislation for disposal through land application. Furthermore, the COD frequently exceeded $5000 \mathrm{mg} / \mathrm{L}$, the threshold where wastewater may not be used for irrigation, or any other land application (Department of Water Affairs, 2013).

Annually, the wastewater COD tended to peak during the harvest period (Fig. 2D). This confirmed that the crushing and wine making processes generated wastewater containing high levels of COD.
Iron: The fluctuation in levels of Fe could not be related to a specific seasonal activity in the winery (Fig. 3). The Fe levels were below the maximum acceptable water quality norm of $5 \mathrm{mg} / \mathrm{L}$ for continuous irrigation of grapevines most of the time (Howell \& Myburgh, 2013 and references therein).

TDS: The fluctuation in levels of total dissolved solids (TDS) could not be related to a specific seasonal activity in the winery (Fig 4). However, almost throughout the study period the TDS was higher than $450 \mathrm{mg} / \mathrm{L}$, i.e. the upper threshold for unrestricted use for irrigation (Ayers \& Westcot, 1994).

\section{Rainfall and volumes of wastewater applied}

Mean monthly rainfall was typical for a Mediterranean climate (Fig. 5). However, it must be noted that the July rainfall was abnormally low in all the winters. Winter rainfall, from April to September, amounted to $380 \mathrm{~mm}, 420 \mathrm{~mm}$ and $685 \mathrm{~mm}$ in 2011, 2012 and 2013, respectively. As expected, wastewater irrigations were substantially higher in the harvest period, i.e. from February until April (Fig. 6). During the peak period, in March, c. $23 \mathrm{~mm}$ irrigation was applied per day. In December, the soil received only c. $3 \mathrm{~mm}$ wastewater per day. The irrigation volumes also increased from mid-winter to reach a second peak in August. Total irrigation applied during winter, i.e. from April to September, amounted to $1475 \mathrm{~mm}, 2600 \mathrm{~mm}$ and $3285 \mathrm{~mm}$ in 2011, 2012 and 2013, respectively. Based on the foregoing, the soil received the highest irrigation plus rainfall in the winter of 2013, followed by 2012 and then 2011 .
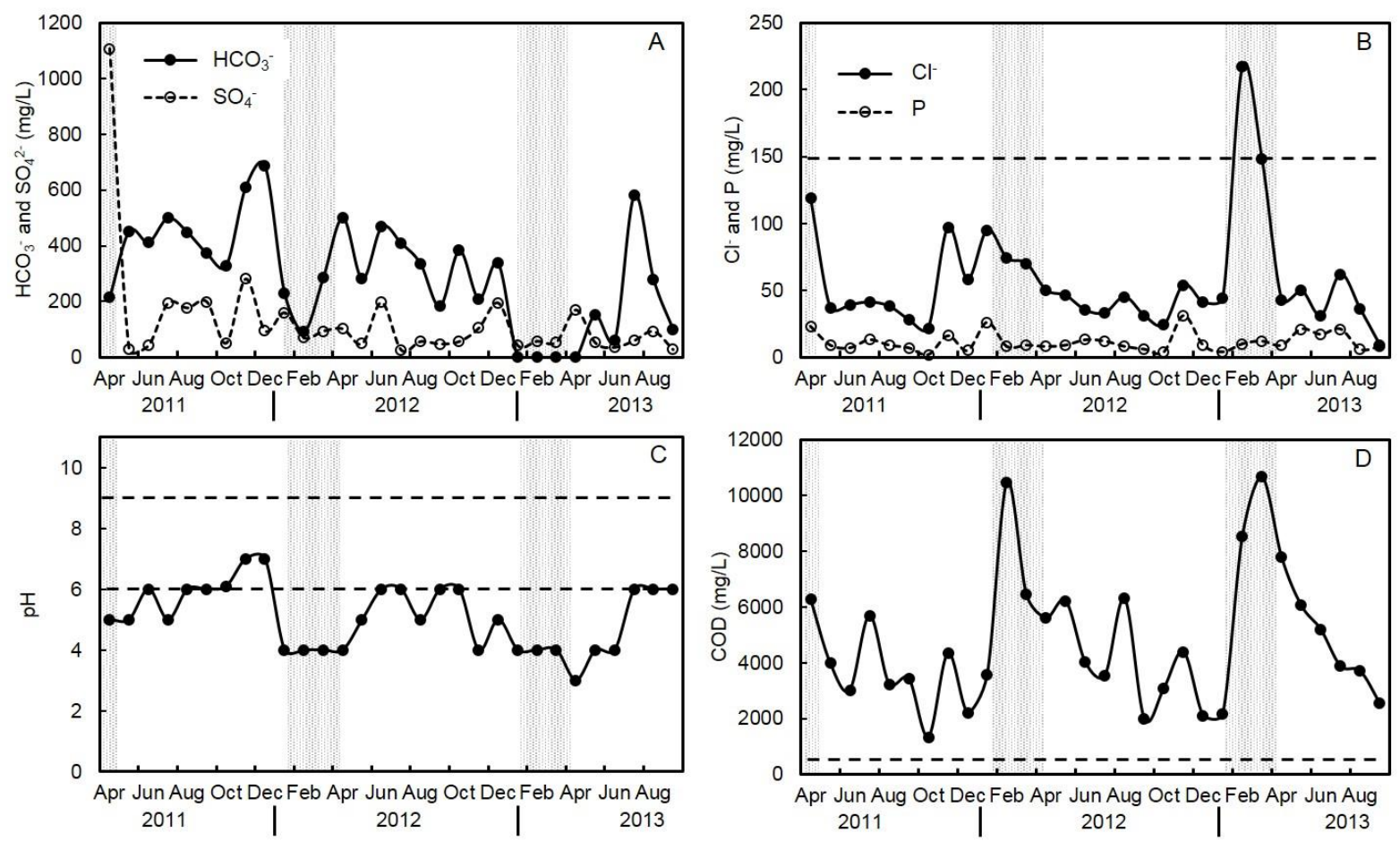

FIGURE 2

Temporal variation in (A) $\mathrm{HCO}^{-}$and $\mathrm{SO}^{2-},(\mathrm{B}) \mathrm{Cl}^{-}$and $\mathrm{P},(\mathrm{C}) \mathrm{pH}$ and (D) chemical oxygen demand (COD) in wastewater from a winery near Rawsonville. Shaded columns indicate the harvest periods. Dashed lines indicate $\mathrm{Cl}^{-}, \mathrm{pH}$ and $\mathrm{COD}$ thresholds. 


\section{Pre-trial soil chemical status}

At the start of the trial, the paddock had been irrigated for 15 years with winery wastewater. Thus the starting composition is not of a pristine soil, but that of an already affected soil. The pre-trial composition serves as time zero for the three seasons of irrigation water applied and the chemical parameters measured. The topsoil has an extremely low clay content $(3.3 \%)$, which will favour a high hydraulic

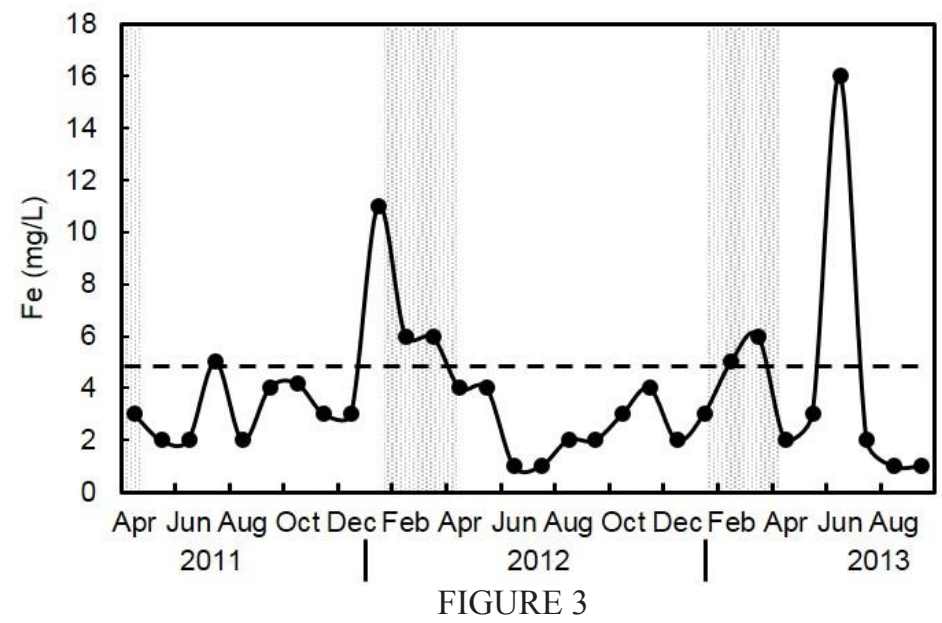

Temporal variation of the iron in winery wastewater used to irrigate an existing grazing paddock at a winery near Rawsonville.

Shaded columns indicate the harvest periods. The dashed line indicates the maximum $\mathrm{Fe}^{2+}$ level for continuous irrigation.

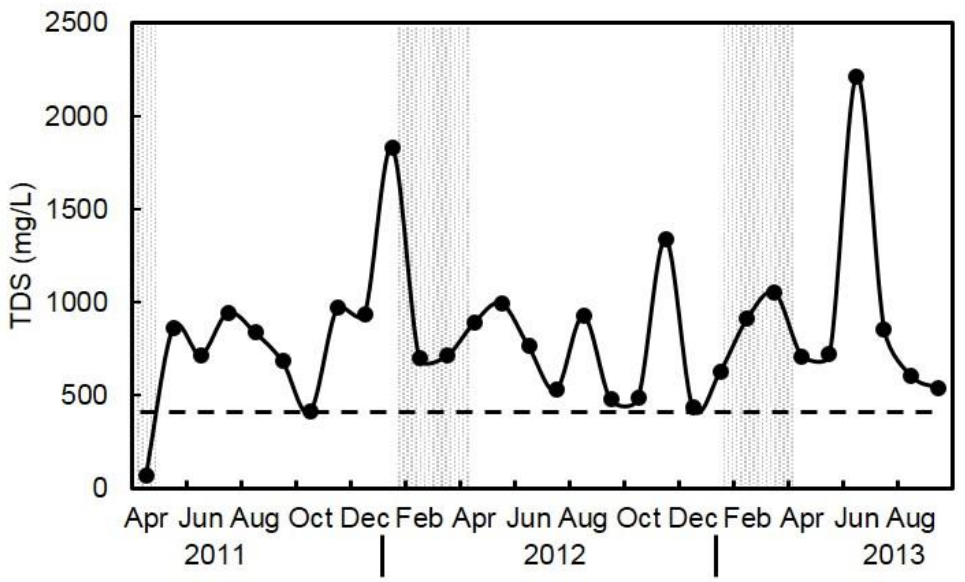

FIGURE 4

Temporal variation of the iron and total dissolved solids (TDS) in winery wastewater used to irrigate an existing grazing paddock at a winery near Rawsonville. Shaded columns indicate the harvest periods. The dashed line indicates the limit for unrestricted irrigation use.

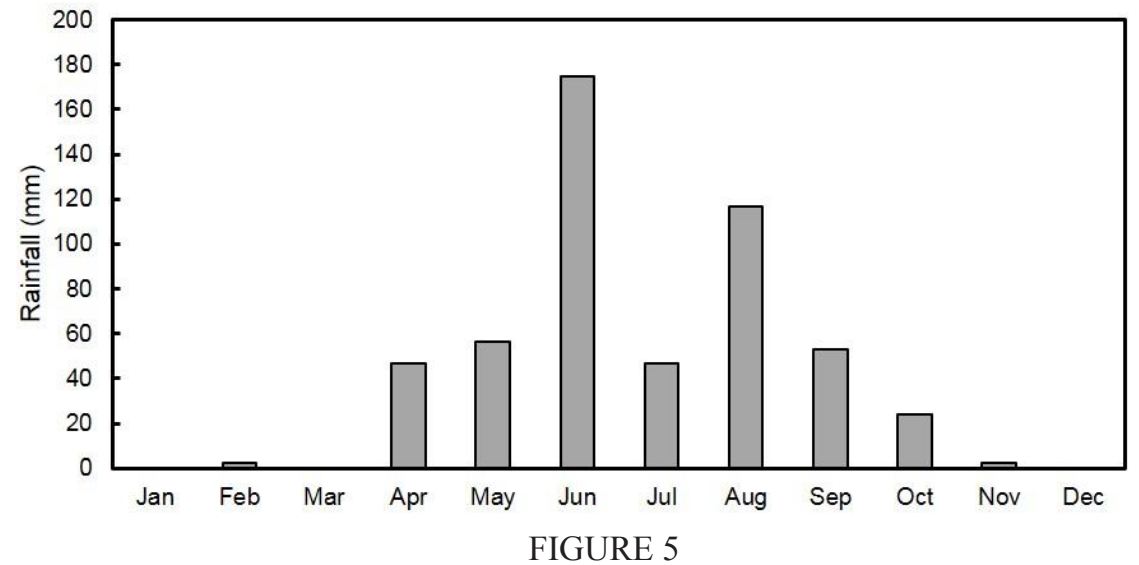

Mean monthly rainfall during the study period at the winery near Rawsonville. 
conductivity and rapid leaching. After continuous irrigation with winery wastewater for 15 years, the soil was acidic throughout the profile, i.e. the $\mathrm{pH}_{(\mathrm{KCl})}$ was less than 4.5. Soil Bray II P was high in all soil layers, i.e. more than $20 \mathrm{mg} / \mathrm{kg}$ which is considered to be the norm for sandy soils (Conradie, 1994). The basic cations declined with depth. By far the highest concentration of all cations occurred in the $0-10 \mathrm{~cm}$ layer. These levels were relatively high for sandy soils (Conradie, 1994). The $\mathrm{Ca}^{2+}{ }_{\text {extr }}$ was the dominant cation, whereas $\mathrm{Na}^{+}$extr was the lowest throughout the profile. The EPP' was relatively high in the deepest soil layers. In contrast, the ESP' was highest near the soil surface.

\section{Soil chemical status during the study period}

Organic carbon: Soil organic C in the $0-10$ and $10-20 \mathrm{~cm}$ layers was substantially higher than 2\% (Fig. 7), which is relatively high for soils of the Western Cape wine regions (Conradie, 1994). This indicated that organic matter applied via the winery wastewater had accumulated in the layers near the soil surface. Except for May 2012, when the organic $\mathrm{C}$ in the $0-10 \mathrm{~cm}$ layer showed a peak, it tended to remain constant over the two-and-a-half-year period. The sludge observed at the surface probably contributed to the exceptionally high organic carbon in the $0-10 \mathrm{~cm}$ layer. Furthermore, it must be noted that the organic carbon at the end of the study was comparable to the initial level at the beginning of the study in March 2011. The organic carbon in the 10-20 cm layer showed an increase until May 2012. This suggested that some of the organic matter had leached into the soil due to the high irrigation volume. The organic carbon in the 10-20 $\mathrm{cm}$ layer tended to remain constant from May 2012 until the end of the study period. The organic carbon in the $20-30 \mathrm{~cm}$ layer tended to decline following November 2011. At this stage, there is no explanation for this trend. Since the organic carbon in the deeper layers remained almost unchanged, it is unlikely that organic carbon could have leached from the 20-30 cm layer into these layers.

Potassium: The application of winery wastewater increased the $\mathrm{K}_{\text {extr }}^{+}$levels in the $0-10 \mathrm{~cm}$ layer, and to some extent in the 10-20 cm layer, at the end of the harvest periods (Fig. 8A). Despite the seasonal fluctuations, $\mathrm{K}^{+}{ }_{\text {extr }}$ steadily increased over the three years in the first two soil layers compared to the levels at the beginning of the study. After three years of wastewater application there was no significant increase in $\mathrm{K}^{+}{ }_{\text {extr }}$ levels deeper than $20 \mathrm{~cm}$ depth (Fig. 8A). Since there was little change in $\mathrm{K}^{+}$levels with depth throughout the profile, it suggested that most of the applied $\mathrm{K}^{+}$was leached beyond $90 \mathrm{~cm}$. Due to the low clay content of the soil, the exchange complex could not retain large amounts of $\mathrm{K}^{+}$. Therefore, leaching of $\mathrm{K}^{+}$beyond

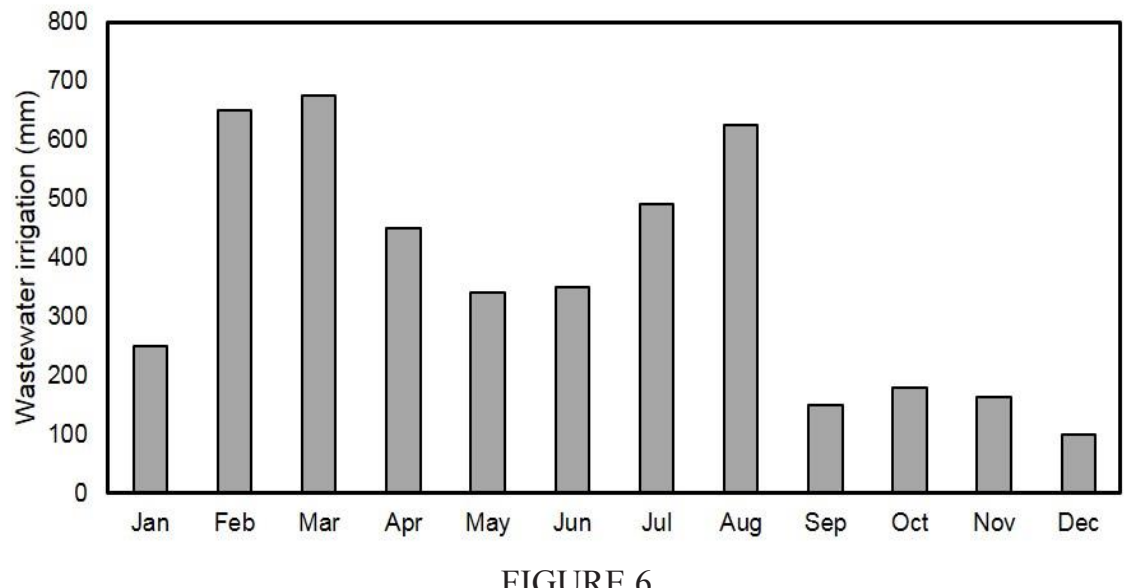

Mean monthly wastewater applied during the study period at the winery near Rawsonville.

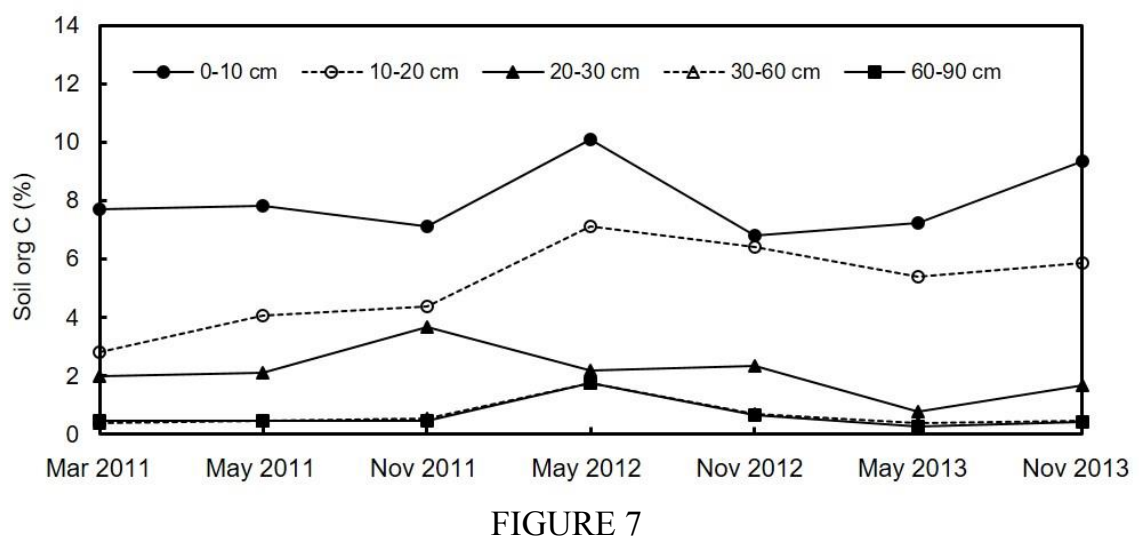

Temporal variation in soil organic $\mathrm{C}$ where winery wastewater was applied to a Longlands soil near Rawsonville. 

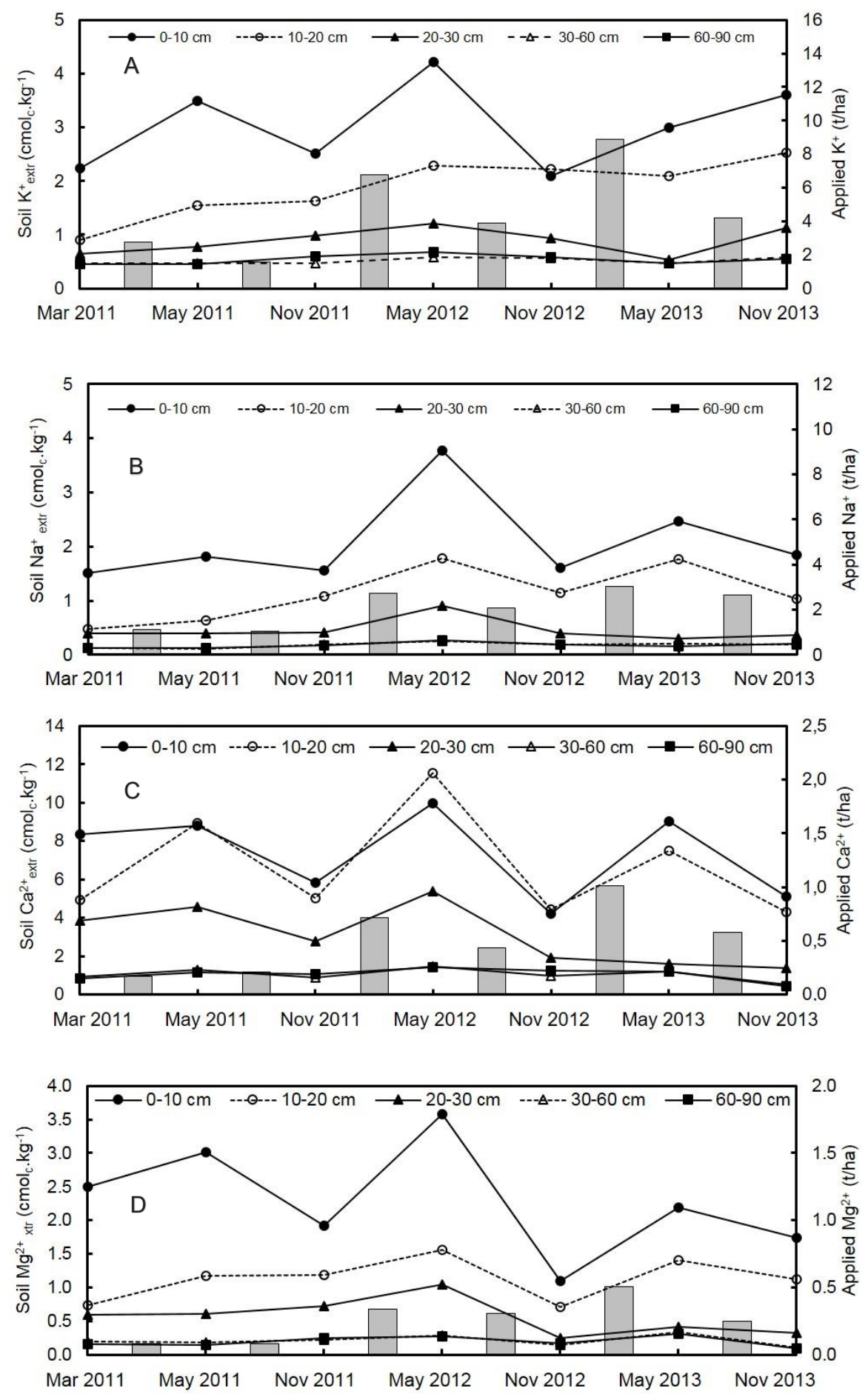

FIGURE 8

Temporal variation in soil extractable (A) $\mathrm{K}^{+}$, (B) $\mathrm{Na}^{+}$, (C) $\mathrm{Ca}^{2+}$ and (D) $\mathrm{Mg}^{2+}$ where wastewater was applied to a Longlands soil near Rawsonville. Vertical columns indicate applied $\mathrm{K}^{+}, \mathrm{Na}^{+}, \mathrm{Ca}^{2+}$ and $\mathrm{Mg}^{2+}$.

$90 \mathrm{~cm}$ was not inhibited. Although leaching of $\mathrm{K}^{+}$from sandy or coarse textured soils during winter rainfall reduces the risk of accumulation and clay dispersion, it increases environmental risks such as groundwater recharge and/or lateral flow into other fresh water resources.

Sodium: Similar to $\mathrm{K}_{\text {extr }}^{+}$irrigation with winery wastewater increased the $\mathrm{Na}^{+}{ }_{\text {extr }}$ levels in the $0-10 \mathrm{~cm}$ and in the 10-20 cm layers, at the end of the harvest periods (Fig. 8B). In May 2012, the $\mathrm{Na}^{+}$extr was also slightly higher in the 20-30 cm layer compared to the rest of the study period. Despite the seasonal fluctuations, $\mathrm{Na}^{+}$extr tended to increase slightly over the two-and-a-half-year study period in the first two soil layers compared to the levels at the beginning of the study. At the end of the study period, there was no increase in $\mathrm{Na}^{+}{ }_{\text {extr }}$ deeper than $20 \mathrm{~cm}$ depth (Fig. 8B). Since there was little change in $\mathrm{Na}^{+}$extr levels with depth throughout the profile, it suggested that most of the applied $\mathrm{Na}^{+}$was leached beyond $90 \mathrm{~cm}$. Similar to $\mathrm{K}^{+}$, the low clay content of the soil 
could probably not retain large amounts of $\mathrm{Na}^{+}$. Therefore, leaching of $\mathrm{Na}^{+}$beyond $90 \mathrm{~cm}$ was also not inhibited. Although leaching of $\mathrm{Na}^{+}$from sandy or coarse textured soils during winter rainfall also reduces the risk of accumulation and dispersion, it poses the same environmental risks as the large amounts of $\mathrm{K}^{+}$that were leached from the soil. High concentrations of $\mathrm{Na}^{+}$in soil due to winery wastewater application can reduce soil aggregate stability (Laurenson \& Houlbrooke, 2012). When $\mathrm{Na}^{+}$is the predominant adsorbed cation, the clay disperses. When the soil is wet, puddling reduces permeability, and when it is dry, a hard impermeable crust forms.

Calcium: The $\mathrm{Ca}^{2+}{ }_{\text {extr }}$ in the $0-10 \mathrm{~cm}$ and $10-20 \mathrm{~cm}$ layers, and to a lesser extent in the $20-30 \mathrm{~cm}$ layer, tended to increase at the end of the harvest period (Fig. 8C). This was followed by a decline during winter. It is interesting to note that the seasonal variation in $\mathrm{Ca}^{2+}$ extr occurred in the 30 $60 \mathrm{~cm}$ layer, although the concentrations were considerably lower compared to the topsoil. A previous study showed that continuous application of winery wastewater high in $\mathrm{K}^{+}$and $\mathrm{Na}^{+}$could cause the soil exchange sites to be dominated by monovalent ions, thereby pushing bivalent ions such as $\mathrm{Ca}^{2+}$ and $\mathrm{Mg}^{2+}$ out of the exchange complex (Mosse et al., 2011). Consequently, the bivalent cations could be leached from the soil. However, the $\mathrm{Ca}^{2+}$ extr in the deeper layers remained constant throughout the study period under the prevailing conditions. Although $\mathrm{Ca}^{2+}$ levels were generally low in the winery wastewater, it seemed that higher applications during the harvest period reflected in the $\mathrm{Ca}^{2+}{ }_{\text {extr. }}$. Since the applied $\mathrm{Ca}^{2+}$ was substantially lower than amounts of $\mathrm{K}^{+}$and $\mathrm{Na}^{+}$, it is unlikely that the $\mathrm{Ca}^{2+}$ would affect the $\mathrm{EPP}^{\prime}$ or $\mathrm{ESP}^{\prime}$ significantly. Therefore, the bivalent cations will probably not counter structural problems caused by high amounts of $\mathrm{K}^{+}$and $\mathrm{Na}^{+}$from the wastewater when applied to the soil.

Magnesium: The $\mathrm{Mg}^{2+}$ extr in the $0-10 \mathrm{~cm}$, and to a lesser extent in the 10-20 cm layer, showed the same seasonal fluctuation as the $\mathrm{Ca}^{2+}{ }_{\text {extr }}$ (Fig. 8D). The $\mathrm{Mg}^{2+}{ }_{\text {extr }}$ in the deeper layers remained more or less constant throughout the study period. Although $\mathrm{Mg}^{+}$levels were generally low in the winery wastewater, it seemed that higher applications during the harvest period also reflected in the $\mathrm{Mg}^{2+}$ extr. Similar to $\mathrm{Ca}^{2+}$, the low levels of $\mathrm{Mg}^{2+}$ are unlikely to counter the negative effects of high $\mathrm{K}^{+}$and $\mathrm{Na}^{+}$applications on $\mathrm{EPP}^{\prime}$ or $\mathrm{ESP}^{\prime}$, and consequently on soil physical conditions.

EPP': With the exception of the 0-10 cm layer, the EPP' tended to be lower at the end of the harvest period, followed by an increase during winter (Fig. 9A). This result is somewhat unexpected, since the higher EPP' did not correspond with the higher $\mathrm{K}^{+}$applications which caused higher $\mathrm{K}^{+}{ }_{\text {extr }}$ in the soil (Fig.8A). Although substantially more $\mathrm{K}^{+}$than $\mathrm{Ca}^{2+}$ was applied via the wastewater, $\mathrm{Ca}^{2+}$ was the dominant cation in all the soil layers, except in November 2013 when the $\mathrm{Ca}^{2+}{ }_{\text {extr }}$ levels were comparable to the other extractable cations in the deeper layers (Fig. 10). The source of the $\mathrm{Ca}^{2+}$ was probably lime that was added to the wastewater in order to increase the $\mathrm{pH}$ as part of the wastewater treatment carried out by the winery. Routine use of $\mathrm{Ca}^{2+}$ amendments including, yet not restricted to lime, gypsum and calcium nitrate, either added directly to wastewater or to soils will enable $\mathrm{Ca}^{2+}$ exchange and displacement of $\mathrm{Na}^{+}$and $\mathrm{K}^{+}$. Winter application of $\mathrm{Ca}^{2+}$ amendments will ensure its percolation down the soil profile, thereby ensuring good distribution of $\mathrm{Ca}^{2+}$ (Laurenson \& Houlbrooke, 2012). Quantification of this practice was beyond the scope of the study. In November 2013, the winery probably reduced, or stopped the lime application, which caused the low soil $\mathrm{Ca}^{2+}{ }_{\text {extr }}$. Based on the foregoing, it seemed that high levels of $\mathrm{Ca}^{2+}$ extr at the end of the harvest dominated the exchange complex to such an extent that the $\mathrm{EPP}^{\prime}$ was reduced compared to the winter when the $\mathrm{Ca}^{2+}{ }_{\text {extr }}$ was lower. The high EPP' in November 2013 was due to the low $\mathrm{Ca}^{2+}{ }_{\text {extr }}$. These results also suggested that the large amounts of applied $\mathrm{K}^{+}$via the winery wastewater were not preferentially absorbed onto the exchange sites.

$\boldsymbol{E S} \boldsymbol{P}^{\prime}$ : Although the $\mathrm{Na}^{+}{ }_{\text {extr }}$ showed some seasonal fluctuations, it did not reflect in the $\mathrm{ESP}^{\prime}$ (Fig. 9B). The lack of seasonal fluctuations in $\mathrm{ESP}^{\prime}$ was probably due to the dominance of $\mathrm{Ca}^{2+}{ }_{\text {extr }}$, and to some extent $\mathrm{K}^{+}$extr . It was previously reported that the adsorption of $\mathrm{Na}^{+}$on soils similar to the Longlands soil was reduced by the presence of high levels of $\mathrm{K}^{+}$after winery wastewater irrigation (Mulidzi et al., 2016).

High soil ESP' increases the risk of soil physical properties to deteriorate through clay dispersion which will lead to structural breakdown and blockage of soil pores and reduced soil permeability (Bond, 1998). However, since the ESP' was relatively low, it would probably not have caused serious soil physical deterioration.

$\boldsymbol{E} \boldsymbol{C}_{e}$ : The salt content remained constant to a depth of 60 cm until May 2012, during which time the $\mathrm{EC}_{\mathrm{e}}$ in the 60-90 $\mathrm{cm}$ layer tended to incline steadily (Fig. 9C). Following the winter of 2012, $\mathrm{EC}_{\mathrm{e}}$ in the deepest two soil layers declined. A similar trend also occurred in the winter of 2013. This could also have been a result of groundwater movement in the bottom of the profile. In fact, $\mathrm{EC}_{\mathrm{e}}$ in all layers tended to be lower following May 2013. These results indicated that the high irrigation plus rainfall must have leached some of the salts applied via the winery wastewater irrigation beyond 90 $\mathrm{cm}$ depth, particularly in the last two winters.

$\boldsymbol{p} \boldsymbol{H}_{(K C l)}$ : Irrigation with winery wastewater slightly increased the soil $\mathrm{pH}_{(\mathrm{KCl})}$ until May 2012 (Fig. 9D). In November 2012, the soil $\mathrm{pH}_{(\mathrm{KCl})}$ showed a decrease and tended to remain constant until November 2013. Variation in soil $\mathrm{pH}_{(\mathrm{KCl})}$ was not related to variation in monovalent cations (data not shown). However, addition of organic acids from winery wastewater could be associated with the decrease of soil $\mathrm{pH}$ due to $\mathrm{H}^{+}$dissociation from carboxyl functional groups (Rukshana et al., 2012). While the soil $\mathrm{pH}$ increase could be associated with high concentration of total alkalinity in wastewater that contains bicarbonate ions, as well as deprotonated organic acids, the charge of these ions are countered by cations. When applied to soils, it increases the $\mathrm{pH}$ due to anion hydrolysis reactions and decarboxylation (Li et al., 2008). It is important to note that the soil was too acidic for viticulture, i.e. $\mathrm{pH}$ less than 5.5 (Conradie, 1994).

Phosphorus: The soil P fluctuations appeared to be erratic (Fig. 11). At certain times, the $\mathrm{P}$ in the topsoil tended to increase, whereas the subsoil $\mathrm{P}$ tended to decline and vice versa. Therefore, it seemed that leaching of $\mathrm{P}$ into the subsoil occurred, which coincided with P losses from the topsoil. This was illustrated more clearly when the means for the topsoil 
(0-30 cm depth) and subsoil (30-90 cm depth) were plotted over time (Fig. 12). It seemed that the increase in subsoil $\mathrm{P}$ lagged behind $\mathrm{P}$ increases in the topsoil up till November 2012. Following this, top and subsoil fluctuations coincided until November 2013. The high rainfall and irrigation before May 2013 probably caused leaching of $\mathrm{P}$ throughout the soil profile. However, this does not rule out the possibility that the low $\mathrm{pH}$ reduced the solubility of the $\mathrm{P}$.

The soil $\mathrm{P}$ content was substantially higher than the minimum requirement recommended by Conradie (1994) for vineyards (Fig. 11). It must be noted that leaching of high levels of $\mathrm{P}$ into groundwater, as well as other fresh
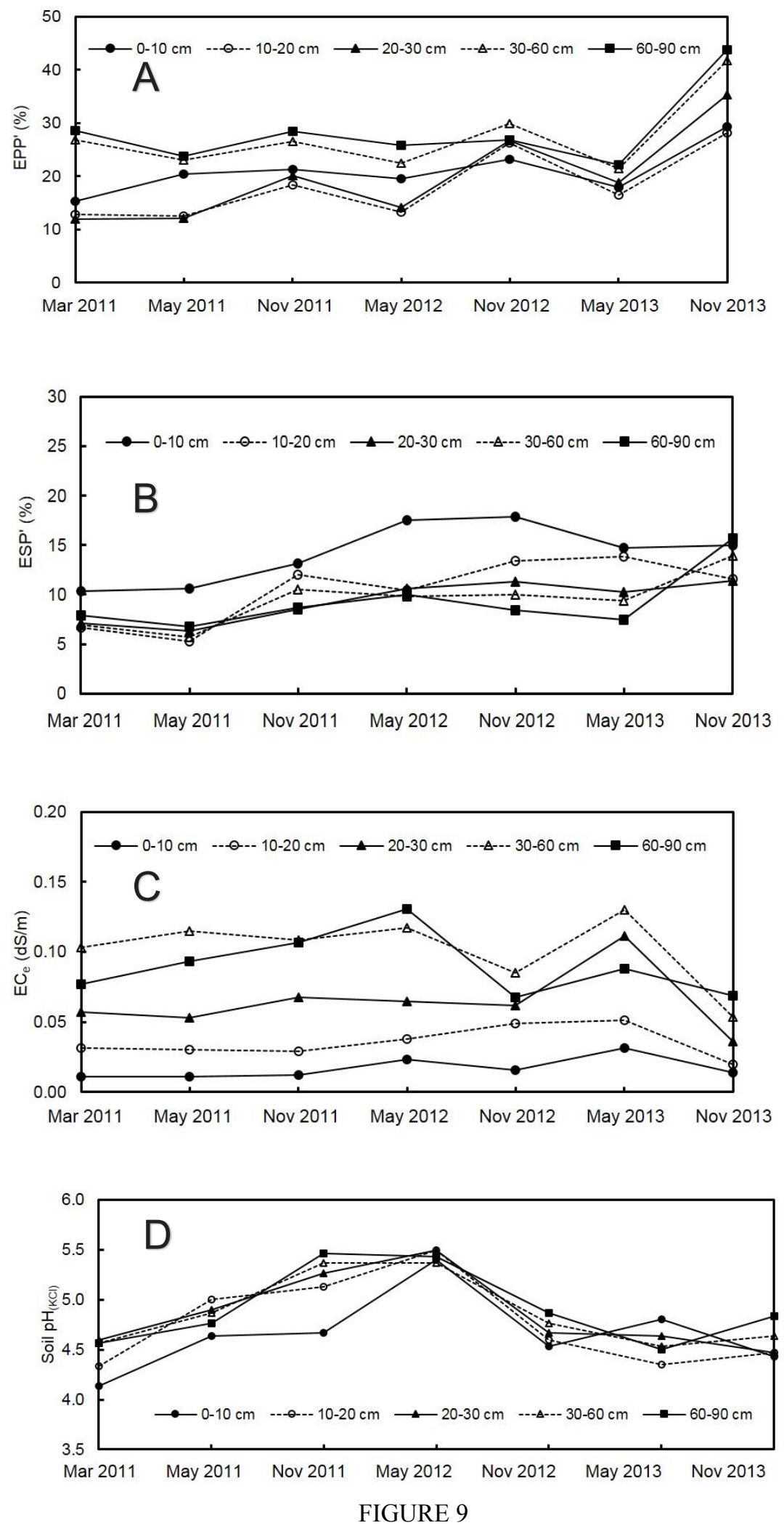

Temporal variation in soil (A) $\mathrm{EPP}^{\prime}$, (B) $\mathrm{ESP}^{\prime},(\mathrm{C}) \mathrm{EC}_{\mathrm{e}}$ and (D) $\mathrm{pH}_{(\mathrm{KCl})}$ where wastewater was applied to a Longlands soil near Rawsonville. 
water sources close to the winery, could cause serious environmental problems, e.g. eutrophication. Due to the sandy nature of the soil, i.e. 3.3\% clay, and low Fe content, it does not have adequate $\mathrm{P}$ adsorbing capacity (Samadi, 2006). This would increase the risk of excessive P leaching from the soil.

\section{CONCLUSIONS}

It is important to note that the study represented the worst-case scenario, i.e. the winery wastewater disposal was carried out in a small paddock. Due to the high volumes of wastewater irrigation plus rainfall, the inevitable over-irrigation leached large amounts of cations, particular $\mathrm{K}^{+}$and $\mathrm{Na}^{+}$, beyond
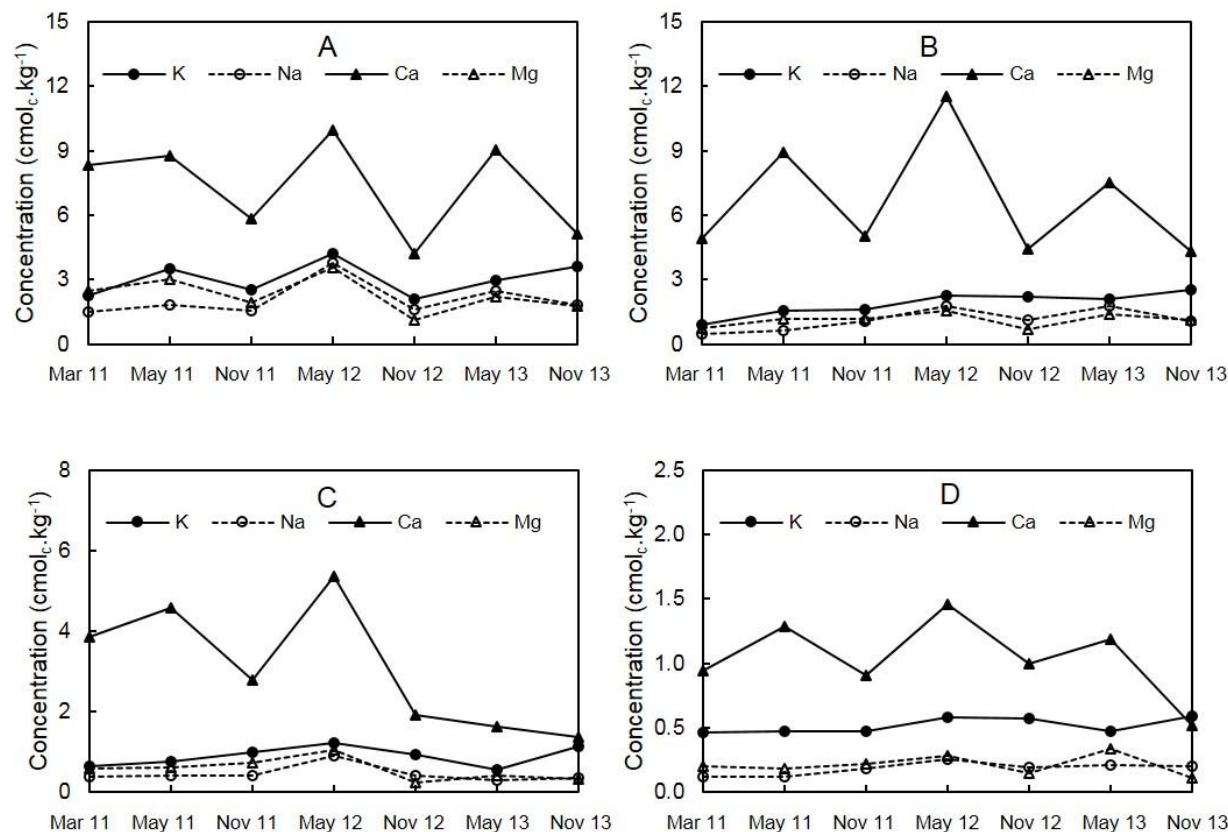

Mar 11 May 11 Nov 11 May 12 Nov 12 May 13 Nov 13

Mar 11 May 11 Nov 11 May 12 Nov 12 May 13 Nov 13

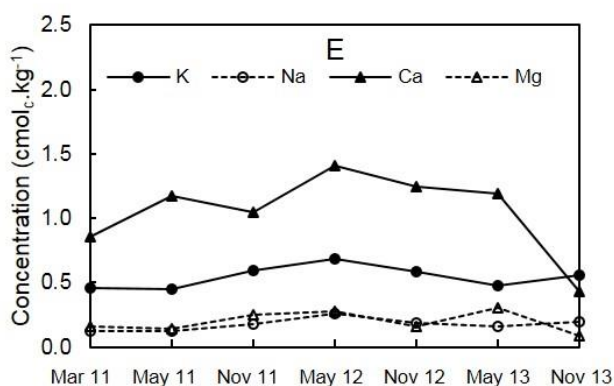

FIGURE 10

Temporal variation of the extractable cations in the (A) 0-10, (B) 10-20, (C) 20-30, (D) 30-60 and (E) 60-90 cm soil layers where winery wastewater was applied to a Longlands soil near Rawsonville.

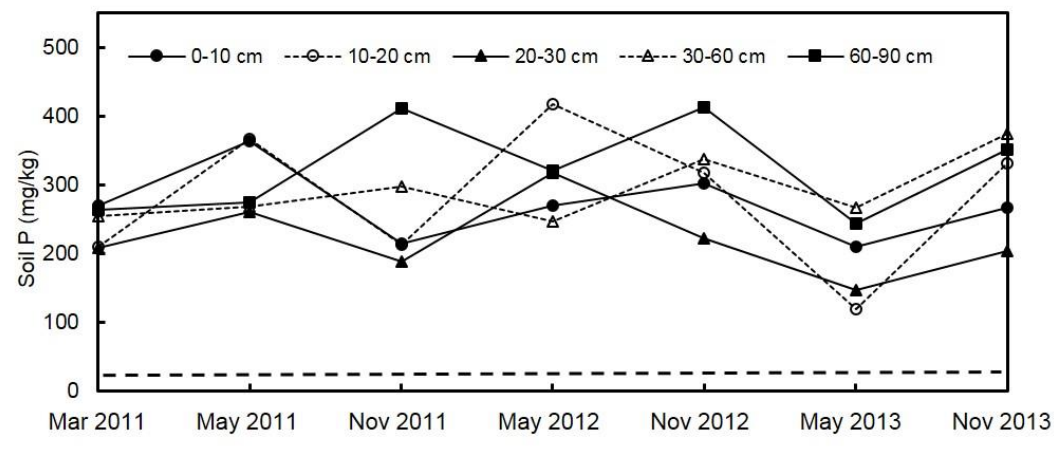

FIGURE 11

Temporal variation in soil $\mathrm{P}$ where wastewater was applied to a Longlands soil near Rawsonville. Dashed line indicate the proposed P norm for grapevines (Conradie, 1994). 


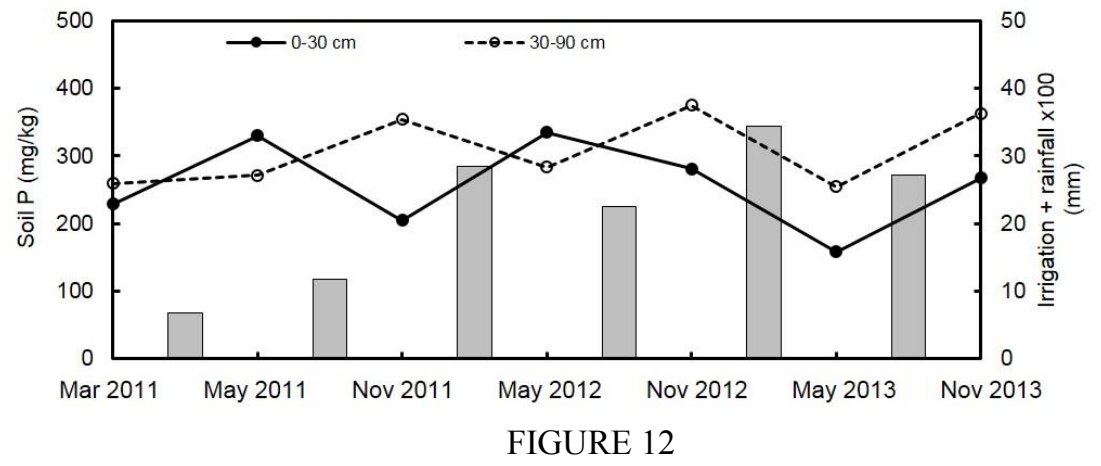

Temporal $\mathrm{P}$ variation in the topsoil $(0-30 \mathrm{~cm})$ and subsoil $(30-90 \mathrm{~cm})$, as well as irrigation plus rainfall where wastewater was applied to a Longlands soil near Rawsonville. Vertical columns indicate irrigation plus rainfall.

$90 \mathrm{~cm}$ depth in the Longlands soil. These leached elements are bound to end up in natural water resources in the long run.

Irrigation with the winery wastewater did not have a pronounced effect on soil $\mathrm{pH}_{(\mathrm{KCl})}$. The study confirmed that injudicious irrigation with untreated winery wastewater poses a serious environmental hazard, particularly where crops in sandy soils are irrigated. Due to the risks involved as discussed above, disposal of winery wastewater by means of over-irrigation is definitely not the ultimate solution to the problem. Land disposal can only be recommended where the wastewater application does not exceed the water requirement of the grazing crop, or any other agricultural crop. Wastewater application according to the $\mathrm{K}^{+}$ requirement of the crop is also crucial. This means that the wastewater needs to be distributed on an area of land that is big enough so that the daily applications do not cause overirrigation. Therefore, sound wastewater management can only be achieved by means of irrigation scheduling based on frequent soil water content measurements. Care should be taken that the irrigation water does not leach beyond the root zone. The soil chemical status should be monitored at least annually. Depending on the type of soil and quality of wastewater, each winery will need to determine the size of land needed for irrigation with their winery wastewater. The effects of $\mathrm{K}: \mathrm{Na}$ ratio in diluted or undiluted winery wastewater on soil structure stability, $\mathrm{K}^{+}$availability and leaching of elements also need to be addressed by continued research. Since the climate, particularly rainfall, will affect the accumulation and/or leaching of elements, it is important that research regarding the effect of wastewater irrigation on soil properties is carried out in field studies in different climatic zones.

\section{LITERATURE CITED}

Arienzo, M., Christen, E.W., Jayawardane, N.S. \& Quayle W.C. 2012. The relative effects of sodium and potassium on soil hydraulic conductivity and implications for winery wastewater management. Geoderma 173, 303-310.

Arienzo, M., Christen, E.W., Quayle, W. \& Kumar, A. 2009. A review of the fate of potassium in the soil-plant system after land application of wastewaters. J. Hazard. Mater. 164, 415-422.

Ayers, R.S. \& Westcot, D.W. 1994. Water quality for agriculture. FAO irrigation and drainage paper no 29. FAO, Rome.
Bond, W.J. 1998. Effluent irrigation - an environmental challenge for soil science. Aus. J.Soil Res. 36, 543-555.

Christen, E.W., Quayle, W.C., Marcoux, M.A., Arienzo, M. \& Jayawardane, N.S. 2010. Winery wastewater treatment using the land filter technique. J. Environ. Manage. 91, 1665-1673.

Conradie, W.J. 1994. Vineyard fertilisation. Proceedings of workshop on vineyard fertilization. Nietvoorbij, 30 September 1994. ARC InfruitecNietvoorbij, Private Bag X5026, 7599 Stellenbosch, South Africa.

Department of Water Affairs. 2013. Revision of general authorizations in terms of Section 38 \& 39 of the National Water Act, 1998 (Act No. 36 of 1998), No. 665. Government Gazette No. 36820, Dept. Water Affairs, Pretoria, South Africa. pp. 3-31.

Hirzel, D.R., Steenwerth, K., Parikh, S.J. \& Oberholster, A. 2017. Impact of winery wastewater irrigation on soil, grape and wine composition. Agr. Water Manage. 180, 178-189.

Howell, C.L. \& Myburgh, P.A. 2013. Permissible element concentrations in water used for grapevine irrigation (Part 2). Anions, trace elements and heavy metals. Wynboer Technical Yearbook. 2013, 59-61.

Howell, C.L. \& Myburgh, P.A. 2018. Management of winery wastewater by re-using it for crop irrigation - A review. S. Afr. J. Enol. Vitic. 36, 116-131.

IUSS Working Group WRB. 2014. World Reference Base for Soil Resources. International classification system for naming soils and creating legends for soil maps. World Soil Resources Reports No.106. FAO, Rome.

Kodur, S. 2011. Effects of juice $\mathrm{pH}$ and potassium on juice and wine quality, and regulation of potassium in grapevines through rootstocks: A short review. Vitis 1, 1-6.

Kumar, A., Saison, C., Grocke, S., Doan, H., Correl, R. \& Kookana, R., 2006. Impact of winery wastewater on ecosystem health-an introductory assessment. Report CSL02/03. Grape and Wine Research Development Corporation/CSIRO Land and Water Science, Adelaide, Australia.

Laker, M.C. 2004. Advances in soil erosion, soil conservation, land suitability evaluation and land use planning research in South Africa. S. Afr. J. Plant Soil 21, 345-368.

Laurenson, S., Bolan, N.S., Smith, E. \& McCarthy, M. 2012. Review: Use of recycled wastewater for irrigating grapevines. Aust. J. Grape Wine Res. $18,1-10$.

Laurenson, S. \& Houlbrooke, D. 2012. Review of guidelines for the management of winery wastewater and grape marc. Report prepared for Marlborough District Council. Agresearch, 1-26.

Li, Z.A., Zou, B., Xia, H.P., Ding, Y.Z., Tan, W.N. \& Fu, S.L. 2008. Role of low-molecule-weight organic acids and their salts in regulating soil $\mathrm{pH}$. Pedosphere 18, 137-148. 
Mosse, K.P.M., Patti, A.F., Christen, E.W. \& Cavagnaro, T.R. 2011. Review: Winery wastewater quality and treatment options in Australia. Aus. J. Grape Wine Res. 17, 111-122.

Mulidzi, A.R. 2016. The effect of winery wastewater irrigation on the properties of selected soils from the South African wine region. Dissertation, Stellenbosch University, Private Bag X1, 7602 Matieland (Stellenbosch), South Africa.

Mulidzi, A.R., Clarke, C.E. \& Myburgh, P.A. 2016. Design of a pot experiment to study the effect of irrigation with diluted winery wastewater on four differently textured soils. Water SA 42, 20-25.

Mulidzi, A.R., Clarke, C.E. \& Myburgh, P.A. 2018. Annual dynamics of winery wastewater volumes and quality and the impact of disposal on poorly drained duplex soils. S. Afr. J. Enol Vitic. 39, 305-314.

Mulidzi, R., Laker, G., Wooldridge, J. 2009. Composition of effluents from wineries in the Western and Northern Cape provinces (Part 2): Impacts on soil and the environment. Wynboer Technical Year book. 62-68.

Ott, R.L. 1998. An Introduction to Statistical methods and data analysis. Belmont, California, Duxbury Press, 807-837.

Quirck, J.P., Schofield, R.K. 1955. The effect of electrolyte concentration on soil permeability. J. Soil Sci. 6, 163-178.

Raath, P.J. 2012. Effect of varying levels of nitrogen, potassium and calcium nutrition on table grape vine physiology and berry quality. Dissertation, Stellenbosch University, Private Bag X1, 7602 Matieland, South Africa.
Rukshana, F., Butterly, C.R., Baldock, J.A. \& Xu, J.M., Tang, C. 2012. Model organic compounds differ in priming effects on alkalinity release in soils through carbon and nitrogen mineralisation. Soil Biol. Biochem. $51,35-43$.

Samadi, A. 2006. Temporal changes in available phosphorus in some calcareous soils. J. Agr. Sci. Technol. 8, 343-349.

Shapiro, S.S., Wilk, M.B. 1965. An analysis of variance test for normality (complete samples), Biometrika 52, 591-611.

Smiles, D.E. \& Smith, C.J. 2004. A survey of the cation content of piggery effluents and some consequences of their use to irrigate soils. Aus. J. Soil Res. 42, 231-246.

Snedecor, G.W. \& Cochran, W.G. 1980. Statistical Methods, $7^{\text {th }}$ Edition, The Iowa State University Press, Ames.

Soil Classification Working Group, 1991. Soil classification - A taxonomic system for South Africa. Memoirs on the Agricultural Natural Resources of South Africa no. 15. Department of Agricultural Development, Pretoria, South Africa.

The Non-Affiliated Soil Analyses Work Committee. 1990. Handbook of standard soil testing methods for advisory purposes. Soil Sci. Soc. S.A., P.O. Box 30030, Sunnyside, Pretoria.

Walkley, A., Black, I.A. 1934. An examination of Degtjareff method for determining soil organic matter and a proposed modification of the chromic acid titration method. Soil Sci. 37, 29-37.

Yan, F., Schubert, S. \& Mengel, K. 1996. Soil pH increase due to biological decarboxylation of organic anions. Soil Biol. Biochem. 28, 617-624. 